\title{
Species of Aylacini Ashmead, 1903 (Hymenoptera: Cynipidae) inducing galls on Papaver L. (Papavaceae) from Romania with description of a new species and notes on parasitoids (Hymenoptera)
}

\author{
Juli PUJADE-VILLAR \\ Universitat de Barcelona, Facultat de Biologia, \\ Departament de Biologia Animal, \\ Avda. Diagonal, 645, E-08028 Barcelona (Spain) \\ jpujade@ub.edu \\ (corresponding author) \\ Ion SCHIOPU \\ Phytosanitary Quarantine Inspectorate, \\ Constanta Port 900900 (Romania) \\ romcleansion@yahoo.com
}

Published on 25 September 2015

KEY WORDS

Cynipidae,

Iraella

Aylax,

Barbotinia

Papaver,

parasitoids,

Romania,

lectotypifications,

new records,

new species.

MOTS CLÉS

Cynipidae, Iraella,

Aylax

Barbotinia,

Papaver,

parasitoïdes,

Roumanie,

lectotypifications, signalements nouveaux

espèce nouvelle.

\begin{abstract}
A new species of Iraella Nieves-Aldrey, 1994 (Cynipidae Latreille, 1802: Aylacini Ashmead, 1903) is described from South East Romania (Dobrudja province), Iraella ionescui n. sp., which induces galls in the base of stems of Papaver rhoeas L. The most important diagnostic characteristics for the adults and galls of the new species are discussed and illustrated. In addition, Aylax papaveris (Perris, 1840), Barbotinia oraniensis (Barbotin, 1964) and Aylax minor Hartig, 1840 are also reported from Romania for the first times. The lectotypes of Barbotinia oraniensis (Barbotin, 1964) and Parnips nigripes (Barbotin, 1964) are designated. A key to all Aylacini species inducing galls on poppies is given. In addition, a list of parasitoids reared from cynipid galls on Papaver spp. is provided.
\end{abstract}

ABSTRACT

\section{RÉSUMÉ}

Les espèces roumaines d'Aylacini Ashmead, 1903 (Hymenoptera: Cynipidae) induisant des galles sur Papaver $L$. (Papaveraceae), avec la description d'une espèce nouvelle et des notes sur leurs parasitö̈des (Hymenoptera). Une nouvelle espèce d'Iraella Nieves-Aldrey, 1994 (Cynipidae Latreille, 1802: Aylacini Ashmead, 1903) est décrite de Roumanie (province de Dobroudja); Iraella ionescui n. sp. induit des galles dans la base des tiges de Papaver rhoeas L. Les caractères diagnosiques les plus importants des adultes et des galles de la nouvelle espèce sont discutés et illustrés. Aylax papaveris (Perris, 1840), Barbotinia oraniensis (Barbotin, 1964) et Aylax minor Hartig, 1840 sont également mentionnées pour la première fois de Roumanie. Les lectotypes de Barbotinia nigripes (Barbotin, 1964) et Parnips nigripes (Barbotin, 1964) sont désignés. Une clé de toutes les espèces d'Aylacini qui induisent des galles dans les coquelicots est présentée. De plus, une liste des parasitoides obtenus à partir des galles de Cynipides sur Papaver spp. est proposée. 


\section{INTRODUCTION}

Aylacini Ashmead, 1903 (Hymenoptera: Cynipidae Latreille, 180 is a paraphyletic tribe (Liljeblad \& Ronquist 1998; Nylander et al. 2004) characterized characterized by its ability to induce galls on herbaceous plants predominantly of the family Asteraceae Bercht. \& J. Presl. More than 120 species are known in the Holarctic region, with the majority of species from the Palaearctic (Melika 2006). The western European genera of the tribe were revised by Nieves-Aldrey (1994).

Five species in three Aylacini genera are associated with poppies (Papaver spp., Papaveraceae Juss.): Barbotinia oraniensis (Barbotin, 1964) and Aylax minor Hartig, 1840 (in capsules of Papaver rhoeas L., P. dubium L., P. hybridum L. and P. argemone L.), Aylax papaveris (Perris, 1840) (in capsules of $P$. rhoeas, P. dubium, P. argemone L. and P. somniferum L.), Iraella hispanica Nieves-Aldrey, 2005 (in flower buds of P. rhoeas and P. dubium) and Iraella luteipes (Thomson, 1877) (in stems of P. somniferum L., P. pseudorientale (Fedde) and P. bracteatum Lindl.). The species described herein, Iraella ionescui n. sp., induces unilocular (sometimes bi- or trilocular) galls at the base of stems of $P$. rhoeas L., and may occasionally be found on $P$. dubium $\mathrm{L}$.

Ionescu (1957, 1973) and Andriescu (1971) mentioned two species from Romania: Aylax papaveris and Barbotinia oraniensis (Barbotin 1964). In this study we reported Aylax minor for the first time from the country and also provided new data on Aylax papaveris and Barbotinia oraniensis.

Around 20 species of parasitoids has been mentioned for Aylacini (Askew et al. 2006). Only three of these species are known from Romania (Andriescu 1971, 1983): Eurytoma infracta Mayr, 1904 (Chalcidoidea: Eurytomidae), Chalcimerus borceai Steffan \& Andriescu, 1962 (Chalcidoidea: Torymidae) and Parnips nigripes (Barbotin, 1964) (Cynipoidea: Figitidae: Parnipinae) and they were all reared from Barbotinia oraniensis galls. In this study the biodiversity of parasitoids in poppies galls is mentioned for the first time from Romania.

\section{MATERIAL AND METHODS}

\section{Methodology}

All material included in this study was collected in Dobrudja province in South East of Romania. We have examined the type material of Barbotinia oraniensis and Parnips nigripes for lectotype designation.

Description of morphological structures follows Liljeblad \& Ronquist (1998) and Melika (2006). Venation abbreviations of the forewing are taken from Ronquist \& Nordlander (1989). Terminology of the cuticle surface is taken from Harris (1979). The material has been determined using Melika (2006), Melika \& Gharaei (2006) and Karimpour et al. (2008).

The SEM images were taken using two dissected, gold coated female specimens in the FEI Quanta 200 Environmental SEM at $10 \mathrm{kV}$. The forewings and galls were photographed with Canon PowerShot SX210 15.

\section{ABBREVIATIONS \\ Morphology \\ $\mathrm{Cu} 1 \mathrm{~b}$ short descending branch of the cubital vein; \\ F1-F12 first and subsequent flagellomeres; \\ LOL lateral-frontal ocellar distance, distance between lateral and frontal ocelli; \\ OOL ocellar-ocular distance, distance from the outer edge of a posterior ocellus to inner margin of the compound eye; \\ POL post-ocellar distance, distance between inner margins of the posterior ocelli; \\ R1 first branch of the radial vein; \\ Rs second branch of the radial vein.}

\section{Institutions}

The type material is deposited in:

AMNH American Museum of Natural History, New York, (J. Carpenter);

CAS California Academy of Sciences, San Francisco, (R. Zuparko);

Coll. JP-V collection J. Pujade Villar provisionally deposited in Universitad de Barcelona (UB)

MNHN Muséum national d'Histoire naturelle, Paris (C. Villemant);

PHMBL Plant Health and Molecular Biology Laboratory, National Food Chain Safety Office (G. Melika);

USNM US National Museum of Natural History, Smithsonian Institution, Washington DC, (M. Buffington).

\section{SYSTEMATICS}

Family CYNIPIDAe Billberg, 1820

Subfamily Cynipinae Billberg, 1820

Tribe AylaCinI Ashmead, 1903

\section{REMARK}

Three Aylacini species associated with Papaver hosts (B. oraniensis, Aylax minor and Aylax papaveris) have been reported previously in Romania and a new species described here: I. ionescui n. sp. The European species associated to poppies can be differentiated according to the following key:

\section{Key to Aylacini Ashmead, 1903 SPECIES INDUCING GALlS ON POPPIES}

1. Head trapezoid, genae straight in front view; malar space slightly shorter than length of compound eye; clypeus not projected above mandibles Barbotinia Nieves-Aldrey, 1994 [Only one species, B. oraniensis (Barbotin, 1964), is included which induces galls inside fruits without causing deformation of the capsule, forming individual spherical galls, 3-5 $\mathrm{mm}$ in diameter]. 
- Head oval to rounded, genae curved in front view; malar space shorter than length of compound eye; clypeus projected above mandibles

2. Lower face with striae radiating from clypeus, elevated median area without striae; mesopleuron, including speculum, with uniform delicate transverse striae; R1 and Rs veins of forewing reaching front margin..... Aylax Hartig, $1840-3$

- Lower face without striae radiating from clypeus; mesopleuron uniformly entirely reticulate or with posterodorsal part smooth and shiny; R1 and Rs veins of forewing not reaching front margin .... Iraella Nieves-Aldrey, $1994-4$

3. Notauli indistinct or absent in anterior $1 / 3$; scutum coriaceous. Galls inside fruits, not deforming capsules, forming individual and separate galls..... A. minor Hartig, 1840

- Notauli complete; scutum coriaceous to coriaceous-rugosae. Galls inside fruit, usually deforming capsules, forming masses of multilocular galls A. papaveris (Perris, 1840)

4. Pronotal plate inconspicuous and sculptured; F1 in female shorter than F2, F1 in males slightly curved; mesopleuron uniformly reticulate; scutellum elongated, delicately coriaceous-reticulate, with scutellar foveae transverse and usually confluent. Radial cell long, at least 3.5 times as long as wide. Galls inconspicuous in stems of poppies .................................................................................................. I. luteipes (Thomson, 1877)

- Pronotal plate conspicuous, smooth; F1 in female as long as F2, F1 in males not modified; posterodorsal part of mesopleuron smooth and shiny; scutellum rugose; foveae small, transverse, and not confluent. Radial cell shorter, around 2.5 times as long as wide. Galls not as above .....

5. F1 without placodeal sensilla; mesoscutum with delicate coriaceous sculpture; mesopleuron with irregular costulate-coriaceous sculpture; medial mesoscutal line inconspicous, very shortly impressed; propodeal carinae narrow and convergent. Galls pluriloculars in aborted flowers ....................... I. hispanica Nieves-Aldrey, 2005

- All flagellomeres with weak placodeal sensilla; mesoscutum with strongly coriaceus sculpture; mesopleuron reticulate; medial mesoscutal line extending $1 / 3$ of scutum length; propodeal carinae inconspicuous and divergent. Unilocular galls in enlarged stems of poppies at the base I. ionescui n. sp.

\section{SPECIES FROM ROMANIA}

Genus Aylax Hartig, 1840

Aylax minor Hartig, 1840

Aylax minor Hartig, 1840: 196.

DistRibution. - Species present in several European countries (Melika 2006) and recently recorded also from Iran (Melika \& Karimpour 2012).

DisTRIBUTION IN ROMANIA. - This is the first record of the species from Romania, collected from the following locations: Comorova forest, 05.VII.1994; Hagieni Natural Reserve 11.VII.1994; Comana-village 20.VII.1995; Fantanita Murfatlar Natural Reserve, 06.VII.1996; Negru Voda-forest 30.VI.1997; Dumbraveni forest 10.VII.2000; Esechioi forest 15.VII.2005; Canaraua FetiiNatural Reserve 20.VII.2010; Valu lui Traian-Natural Reserve, 01.VIII.2012. All localities are in Dobrudja Province in South-East of Romania. Host plant species in Romania includes $P$. rhoeas $\mathrm{L}$. and $P$. dubium L.

GALLS. - Galls (Fig. 4C) irregularly rounded (2-3 $\mathrm{mm}$ in diameter), light yellow, forming numerous individual chambers inside capsules of puppies (mainly in $P$. rhoeas and $P$. dubium), attached to septa of the fruit capsule, originated by the transformation of the seeds. Poppy capsules are not deformed externally, so its presence is not visible from outside.

Comments. - Adults are very similar to A. papaveris, the two species can only be recognized based on slight morphological differences, for this reason Eady \& Quinlan (1963) questioned its differences. Aylax minor has notauli indistinct in the anterior $1 / 3$, sometimes a very few impressions is present in anterior $1 / 3$ (complete in $A$. papaveris), scutum only coriaceous (coriaceous usually with some weak rugosity in $A$. papaveris) and scapus + pedicellum usually lighter than flagellum (uniformly colored $A$. papaveris).

LIFE CYCLE. - Galls start to develop in spring, mature in May to June; adults emerge from capsules next spring. The life history of the species has been accurately studied by Folliot (1964).

\section{Aylax papaveris (Perris, 1840)}

\section{Diplolepis papaveris Perris, 1840: 95.}

Distribution. - Species present in several European countries (Melika 2006) and recently also reported from Iran (Melika \& Karimpour, 2012).

Distrution in Romania. - A papaveris was reported from Romania by Ionescu $(1957,1973)$ in Geoagiu (Hunedoara County) on $P$. dubium and $P$. rhoeas rarely $P$. argemone, and is herein collected in Dobrudja province, South-East of Romania in the following locations: Comana Village, 25.VI.1995; Comorova forest, 29.VI.1997; Hagieni Natural Reserve, 05.VII.1998; Negru Voda forest, 30.06.1999; Eforie - Black Sea coast, 20.VII.2000; Cheia Natural Reserve, 27.VIII.2005; Horia forest, 25.VII.2011.

GALLS. — Fused galls (Fig. 4B) light yellow, forming irregular oval or globular masses highly variable in size, including a few dozen larval chambers arranged perpendicularly to vertical capsule axis. 
The individual gall chambers are originated by the transformation of the septum and seeds, usually causing the deformation and enlargement of the capsules (mainly in $P$. rhoeas and $P$. dubium). Internal septa and seeds disappear.

Comments. - Adults are very similar to $A$. minor (see comments above). Aylax papaveris has notauli complete, scutum coriaceous usually with some weak rugosity and antennae uniformly coloured.

LIFE CYCLE. - Monovoltine species. Biology similar to the previous species.

Genus Barbotinia Nieves-Aldrey, 1994

Barbotinia oraniensis (Barbotin, 1964)

Aylax oraniensis Barbotin, 1964: 152.

TYPE MATERIAL. - Lectotype (here designated). ㅇ (col. F. Barbotin) with the following labels deposited in coll. JP-V: "Mangin, Oranie, 26.3.62, de capsule de P. rhoeas", "Aylax oraniensis B. o" O", "Lectotype of Aylax oraniensis Barbotin, 1964, design. JP-V 2013" (red label), "Barbotinia oraniensis (Barbotin) JP-V det." (white label). Paralectotypes. (22 O", 47 \%) deposited in coll. JP-V: Oran, IIIIV.1962: $130^{*}, 27$ \%; Boutelis, III.1960: $40^{7}, 5$ \%; Misserghin, III.1962: 3 \%; Murdjadjo, III-IV.1962: 4 07, 8 \%; Aïn Beida, III.1962: $10^{7}$; Mangin, III-IV.1962: 4 ㅇ.

TyPe LOCAlity. - Mangin (Oran, Algeria) according to F. Barbotin labels.

DisTRIBUTION. - Mediterranean species described originally from Algeria as Aylax oraniensis (Barbotin 1964) and known from France, Romania, Spain, Italia, Croatia (Istria), Ukraine (Crimea only) and Iran (Andriescu 1971, 1983; Nieves-Aldrey 2001; Melika 2006, Melika \& Karimpour, 2012; Kwast 2012).

In Romania it is known from Agigea Natural Reserve of dune plants and Eforie on the Black Sea coast (Dobrudja province) (Andriescu 1983). Additional specimens of the species sent by Andriescu are deposited in the Barbotin collection: Hagieni Natural Reserve 11.VII.1994, 05.VII.1995; Fantanita Murfatlar Natural Reserve 20.VI.1996, 04.VII.1997; Comorova forest, 03.VII.1998; Comana Village, 24.VII.1999; Sipote forest, 30.VI.2006; Negru Voda forest, 20.VII.2010; Esechioi forest, 25.VII.2011; Canaraua Fetii Natural Reserve, 01.VIII.2012.

GALLS. - Spherical galls (Fig. 4A), 3-5 mm in diameter, more or less irregularly shaped, formed inside capsules (mainly in P. rhoeas and $P$. dubium), in variable number (usually $1-3$ ), resulting in the hypertrophy of internal tissues, with a meridian axes resulting from the rest of the capsule internal septum. The capsule could be slightly deformed externally but the hypertrophy is usually imperceptible.

DiAgNOSIS. - The genus Barbotinia includes a single species and is characterized of having a trapezoidal head, malar space long, antennae 14-segmented in females and 15 in males, mesoscutum coriaceous with piliferous points, notauli complete, medial mesoscutal line extending to $1 / 2$ length of the mesoscutum, scutellar foveae large, mesopleuron reticulate-carinate, radial cell opened, with R1 not reaching wing margin and metasomal tergite II without anterolateral patch of setae.

LIFE CYCLE. - Monovoltine species. Biology similar to the previous species.
Genus Iraella Nieves-Aldrey, 1994

Iraella ionescui $\mathrm{n}$. sp.

(Figs $1-3 ; 4 \mathrm{D}$ )

TYPe MATERIAL. - Holotype Comana-Amzacea (Romania), 10.VI.2012: 1 (Schiopu col.) Ex Papaver rhoeas L. deposited in coll. JP-V.

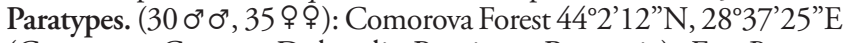
(Constanta County, Dobrudja Province, Romania), Ex. Papaver rhoeas L., 15.VI.1996: $70^{7} 0^{7}, 7$ \% $~ \%$; same data, 10.VI.1996: $20^{7} 0^{7}$; Comana-Pelinu $43^{\circ} 95^{\prime} \mathrm{N}, 28^{\circ} 4^{\prime} \mathrm{E}$ (Constanta County, Dobrudja Province, Romania) Ex. Papaver rhoeas L, 30.VI.1997: 17 o' o", 20 웅 Constanta Port $44^{\circ} 14^{\prime} \mathrm{N}, 28^{\circ} 38^{\prime} \mathrm{E}$ (Constanta County, Dobrudja Province, Romania), Ex. Papaver rhoeas L, 04.VIII.2011: 3 o $^{7}$ ",

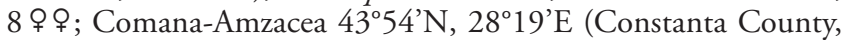
Dobrudja Province, Romania) Ex Papaver rhoeas L., 17.VI.2012: $10^{\circ}$. Paratypes deposited in coll. JP-V. (15 $0^{\circ}, 20$ \%), PHMBL (3 $0^{\prime \prime}$, 3 \%), USNM ( $30^{\prime \prime}, 3$ \%), CAS ( $30^{\circ}, 3$ \%), AMNH $\left(30^{\prime \prime}, 3\right.$ \% ) and MNHN (3 0 , 3 \%).

TYPE LOCAliTY. - Comana-Amzacea (Constanta county, Dobrudja province, Romania) situated at UTM coordinates $43^{\circ} 54^{\prime} \mathrm{N}, 28^{\circ} 19^{\prime} \mathrm{E}$.

ETYMOLOGY. - This species is named in honour of Mihail Andrei Ionescu (1900-1988), a Romanian cynipidologist.

Diagnosis. - The new species resembles I. hispanica, but differs in the following characters: mesoscutum strongly coriaceous (delicately coriaceous in I. hispanica), mesopleuron reticulate (costulate-coriaceous in I. hispanica), medial mesoscutal line present (inconspicuous or absent in I. hispanica) and galls unilocular located at the base of stems (plurilocular in terminal flowers buds in I. hispanica). The new species also resembles I. luteipes, but differs from the latter in having pronotal plate smooth and shiny (reticulate in I. luteipes), F1 in males similar to F2 (slightly modified in I. luteipes), posterodorsal part of mesopleuron smooth and shiny (entirely and uniformly reticulate similar to the scutellum sculpture in I. luteipes), elongated with scutellar foveae differentiated (confluent in I. luteipes), radial cell around 2.5 times as long as wide (3.5 in I. luteipes), stems with galls hypertrophied (unconspicous in $I$. luteipes), and host plants being usually $P$. rhoeas and rarely $P$. dubium (P. somniferum as in $I$. luteipes).

Distribution. - South-East Romania, including the Black Sea coast (Dobrudja province).

Biology. - Monovoltine species. Adults emerge in March-May when the host plant Papaver spp. is developing. Females lay eggs on poppy stems in April-May. Galls grow rapidly, so can be identified in the first half of May. Full development of galls ends in June-July. Larval stage last about 3-4 months and pupation occurs in OctoberNovember. Pupa development takes place in the larval chamber enclosed in a cocoon parchment. Overwintering takes place in gall as adult, whose development is completed sometimes in early December. The galls are synchronous with the other wasp galls from poppy capsules. Optimum time of collection: late June early July of development year. Most prospective parasitoids emerge from galls in June-July the first year and the rest next spring.

\section{DESCRIPTION}

Length

Females: 2.9-3.0 mm ( $\mathrm{n}=7)$; males: 2.2-2.7 mm ( $\mathrm{n}=8)$.

\section{Coloration}

Black; hypopygium, antennal flagellum and legs brown (femur, trochanter and coxa partially black). 

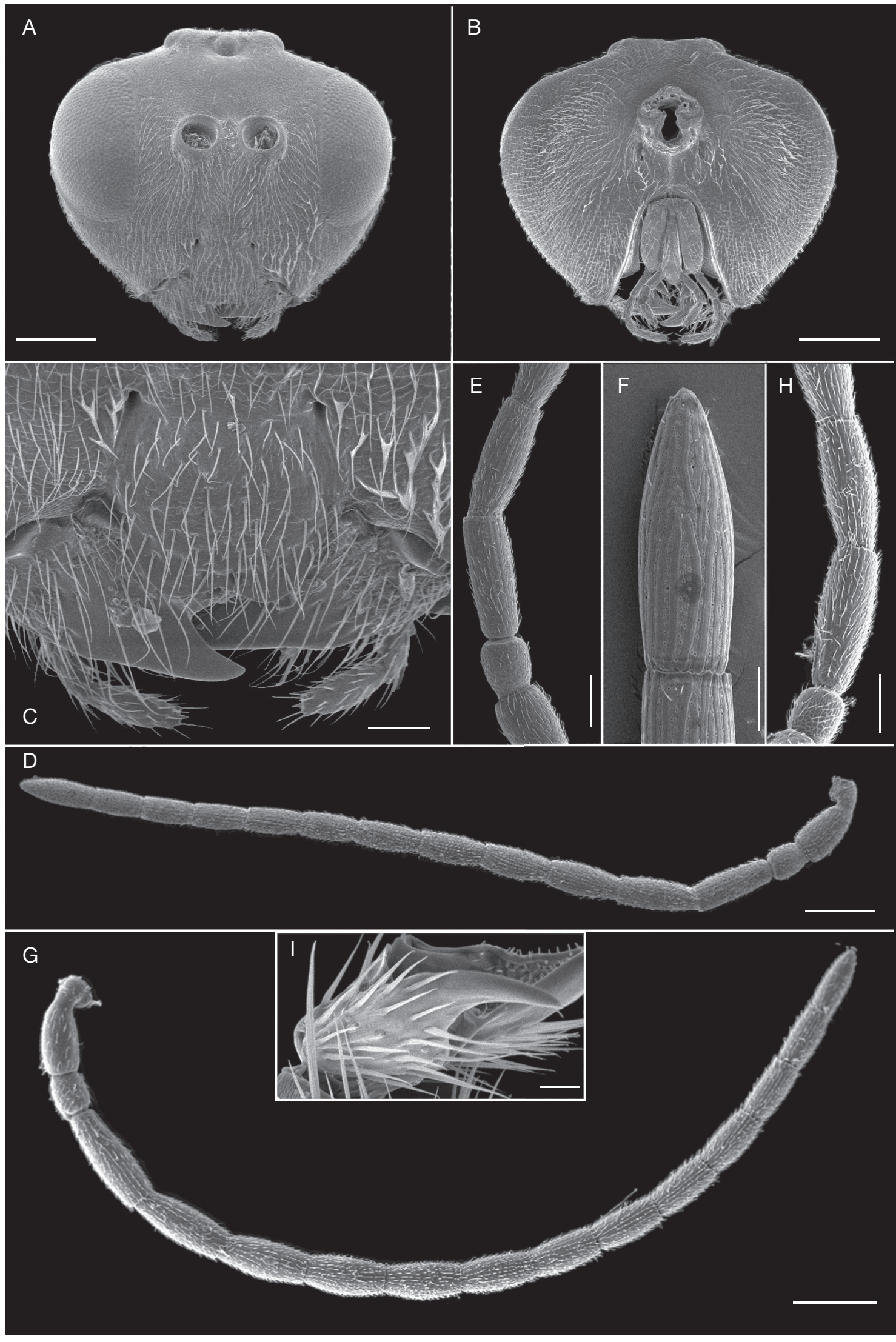

FIG. 1. - Iraella ionescui n. sp.: A, female head in frontal view; B, female head in posterior view; C, detail of clypeus; D, female antenna; E, detail of pecidellum + F1-F2 segments of female antenna; $\mathbf{F}$, detail F12 of female antenna; $\mathbf{G}$, male antenna; $\mathbf{H}$, detail of pecidellum + F1 - F2 segments of male antenna; I, tarsal claws. Scales bars: A, B, D, G, $200 \mu \mathrm{m} ; \mathrm{C}, \mathrm{F}, 50 \mu \mathrm{m} ; \mathrm{E}, \mathrm{H}, 100 \mu \mathrm{m} ; \mathrm{I}, 10 \mu \mathrm{m}$. 
Head (Figs $1 A, B ; 2 A-C$ )

Head in dorsal view slightly more than twice as wide as long. In anterior view oval; 1.3 times as broad as high; lower face pubescent and with uniform coriarious sculpture; facial striae radiating from clypeus completely lacking. Upper face and vertex glabrous and more delicately sculptured than lower face. POL:OOL:OCO equal to 2.7:1.8:1.1 and related to ratio of diameter of lateral ocellus 0.8 . Ocellar plate distinctly raised. Lateral margin of gena slightly curved, malar space around 0.45 times the height of compound eye. Clypeus more or less quadrangular, ventrally projecting over mandibles; ventral clypeal margin weakly incised; distance between anterior tentorial pits longer than the distance between epistomal sulcus and ventral margin of clypeus. Anterior tentorial pits conspicuous. Epistomal sulcus and clypeo-pleurostomal lines impressed, well-marked. Antennal toruli located at mid height of compound eye; distance between antennal rim and compound eye 0.8 times as wide as width of antennal socket including rim. Occiput pubescent, with rugulose sculpture, without occipital carina; some weak irregular transverse rugae present above occipital foramen.

\section{Antennae}

Female antenna (Fig. 1D-F) thin and elongate; 0.9 times as long as body, with 14 antennomeres; flagellum not broadening apically; placodeal sensilla present on all flagellomeres, weakly impressed; antennal formula: $5: 3 \times 2.5: 7 \times 2.5: 7: 6$ : $6: 6: 5: 5: 4.5: 4.5: 4: 4: 7$. Male antenna (Fig. 1G-H) 1.1 times as long as body with 15 antennomeres; $\mathrm{F} 1$ not modified, staright; placodeal sensilla on all flagellomeres, weakly impressed; antennal formula: $5: 3 \times 2.25: 7.5 \times 2.25 .7: 6$ : $5: 5: 5: 5: 5.5: 4.5: 4.5: 5.5: 5$.

\section{Mesosoma (Figs 2C, D; 3A-D)}

In lateral view convex dorsally, slightly longer than high. Dorsal pronotal margin concave in anterior view. Admedian pronotal depressions transversely oval, deep, open laterally, broadly separated medially by a distance as long as admedian depression length. Pronotal plate rectangular defined, hairless and without sculpture. Lateral surface of pronotum weakly coriarious; its dorsal and ventral parts with moderately long and dense pubescence. Mesoscutum 1.2 times as wide as long and 1.7 times as long as scutellum length; with strongly coriaceous sculpture; sparsely pubescent. Median mesoscutal impression distinct in posterior $1 / 3$ of mesoscutum. Notauli complete; narrower and shallower anteriorly, broader, deeper and slightly convergent in posterior third of mesoscutum. Anterior parallel lines and parapsidal lines impressed. Mesoscutum and scutellum separated by a distinct transscutal suture. Scutellum rounded dorsally; strongly curved laterally, very slightly overhanging metanotum. Scutellar foveae ovate, deep, separated by a carina with posterior margins defined. Dorsal surface of scutellum strongly rugose. Axillula densely pubescent. Posterodorsal and posterior margins of axillula distinct. Posterior part of axillular strip extended dorsally. Mesopleuron uniformly reticulate without carinae, posterodorsal part of mesopleuron smooth and shiny, pubescent in lower half. Mesopleural triangle distinctly impressed and densely pubescent, with dorsal and ventral margins clearly marked. Metascutellum conspicuously constricted medially. Bar ventral to metanotal trough almost completely smooth; dorsal bar sculptured and pubescent. Metanotal trough narrow and densely pubescent. Metapleural sulcus slightly above of the mid-height of mesopleuron. Lateral propodeal carinae very weakly impressed, slightly divergent inferiorly. Lateral and median propodeal areas densely pubescent, smooth. Nucha relatively short; dorsally smooth.

\section{Legs}

Tarsal claws simple (Fig. 1I), without a basal lobe but broad basally, with a few long setae.

\section{Forewing (Fig. 2E)}

Slightly longer than body, mostly hyaline, except slight infuscation around 2r, R1, R1 + S and M. Radial cell open along anterior margin, 2.5 times as long as wide. Rs and $2 \mathrm{r}$ curved. Areolet usually present. Cilia along apical margin short.

\section{Metasoma}

Female metasoma (Fig. 3E-G). In lateral view 1.4 times as long as high. Third abdominal tergum covering about half of metasoma, 3.2 times as long as fourth tergum; anteromedial area of third abdominal tergum with sparse setae but not forming a distinct patch. Fourth to seventh terga smooth, bare, with sparse micropunctures. Ventral spine of hypopygium with sparse micropunctures; projecting part short, longer than basal height of spine; ventrally with two double rows of short hairs.

\section{Host plant \\ Papaver rhoeas L. rarely $P$. dubium $\mathrm{L}$.}

\section{Gall (Fig. 4D)}

Unilocular galls are formed in the host plant stem at the base next to the roots (Fig. 4D) difficult to be seen and causing lateral or central deformation of the stem of puppies. The light green colored galls at early development will become yellow-brown as they mature. Most of the time galls are simple (monolocular), but bi- or trilocular galls may be formed by conglomeration of simple galls. Simple galls have an average diameter of approx. 4-5 $\mathrm{mm}$ and the multilocular galls about $10 \mathrm{~mm}$. Host plant tissue with hypertrophy, galls are spherical or ovoid, covered with abundant silvery-white hair pilosity. Inside a gall was a simple larval chamber with no inside gall. In each larval chamber develops a single larva. Gall presence often inhibits the development of the host plant, giving it a stunt appearance. Sometimes plants with galls only reach a height of $4-5 \mathrm{~cm}$. The galls are integral and they remain on the host plant until next spring when adults emerge.

\section{COMMENTS}

Some Aulacidea species as A. pilosellae (Kieffer, 1901), A. scorzonerae (Giraud, 1859) and A. subterminalis (Niblett, 1946), and Isocolus ponticus Dyakonchuk, 1982, can produce galls 

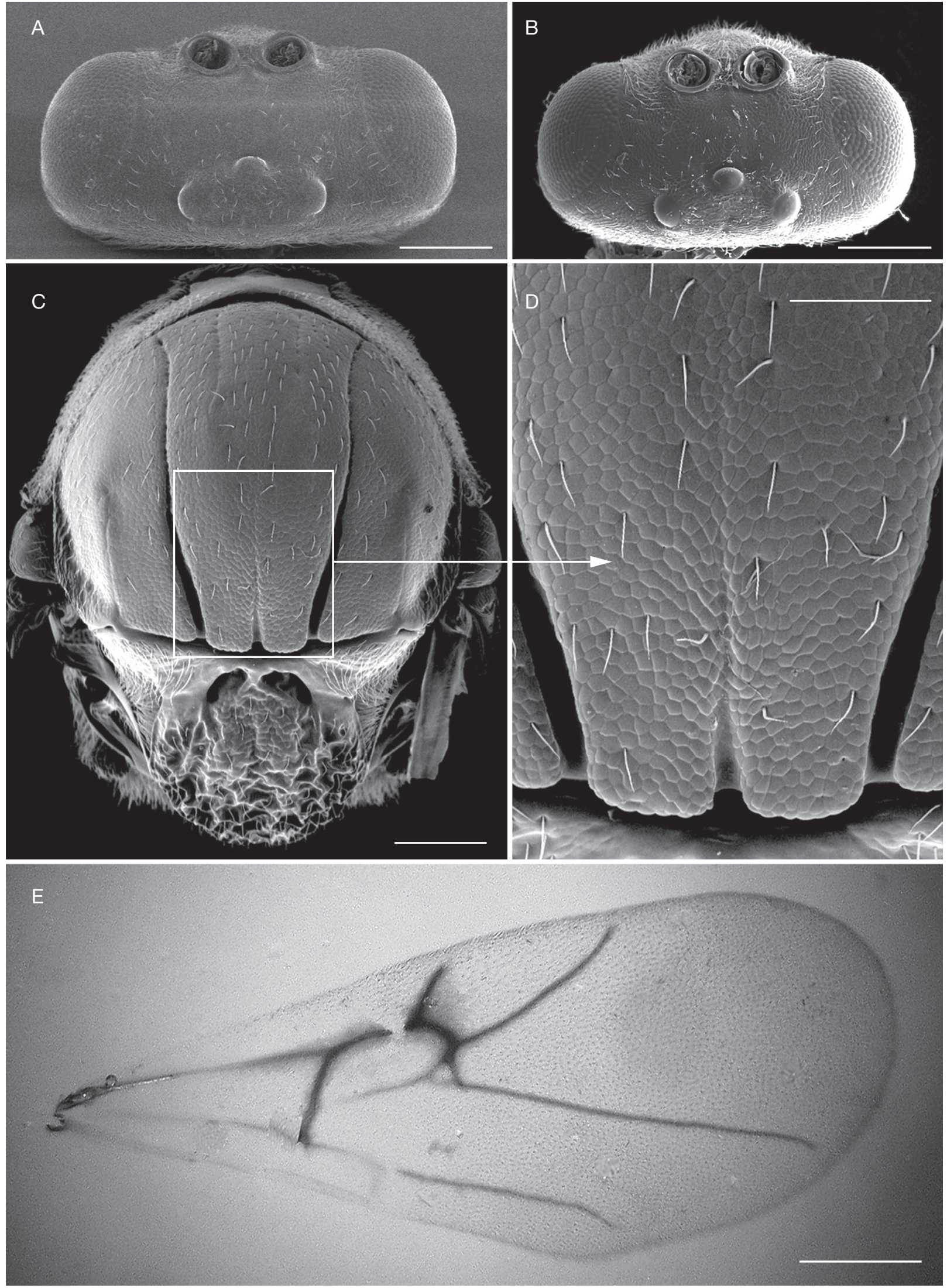

FIG. 2. - Iraella ionescui n. sp.: A, female head in dorsal view; B, male head in dorsal view; C, female mesosoma in dorsal view; D, sculpture detail; E, forewings. Scales bars: A-C, $200 \mu \mathrm{m} ; \mathrm{D}, 100 \mu \mathrm{m}$ and $\mathrm{E}, 0.5 \mathrm{~mm}$. 

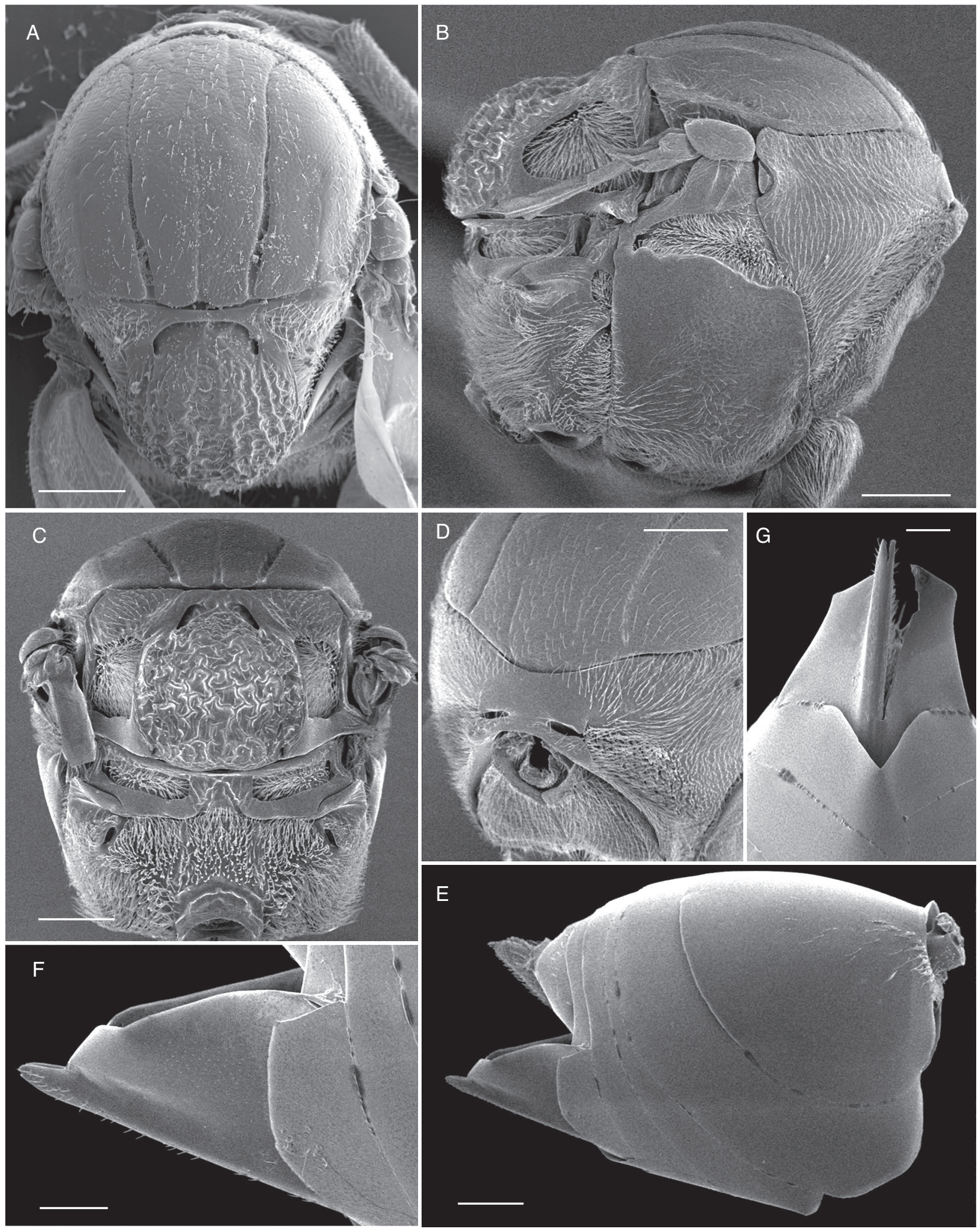

FIG. 3. - Iraella ionescui n. sp.: A, male mesosoma in dorsal view; $\mathbf{B}$, female mesosoma in lateral view; C, female mesosoma in posterior view; $\mathbf{D}$, detail of pronotum; E, metasomal in lateral view; F, detail of hypopygium in lateral view; G, ventral spine and hypopygium in ventral view. Scale bars: A-E, $200 \mu$ m; F, G, $100 \mu$ m. 


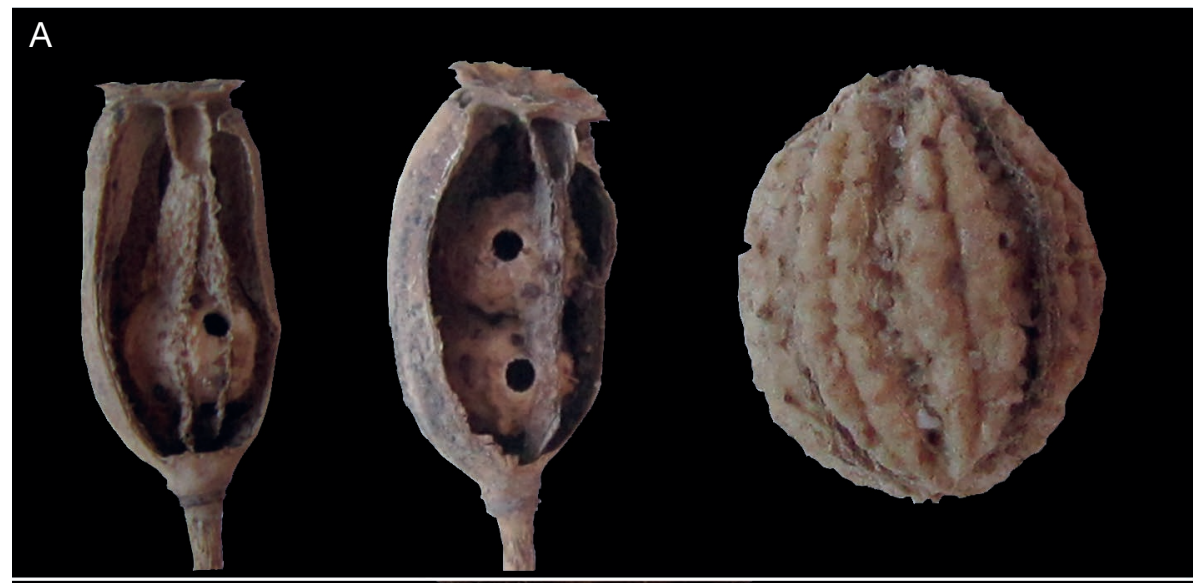

\section{D}
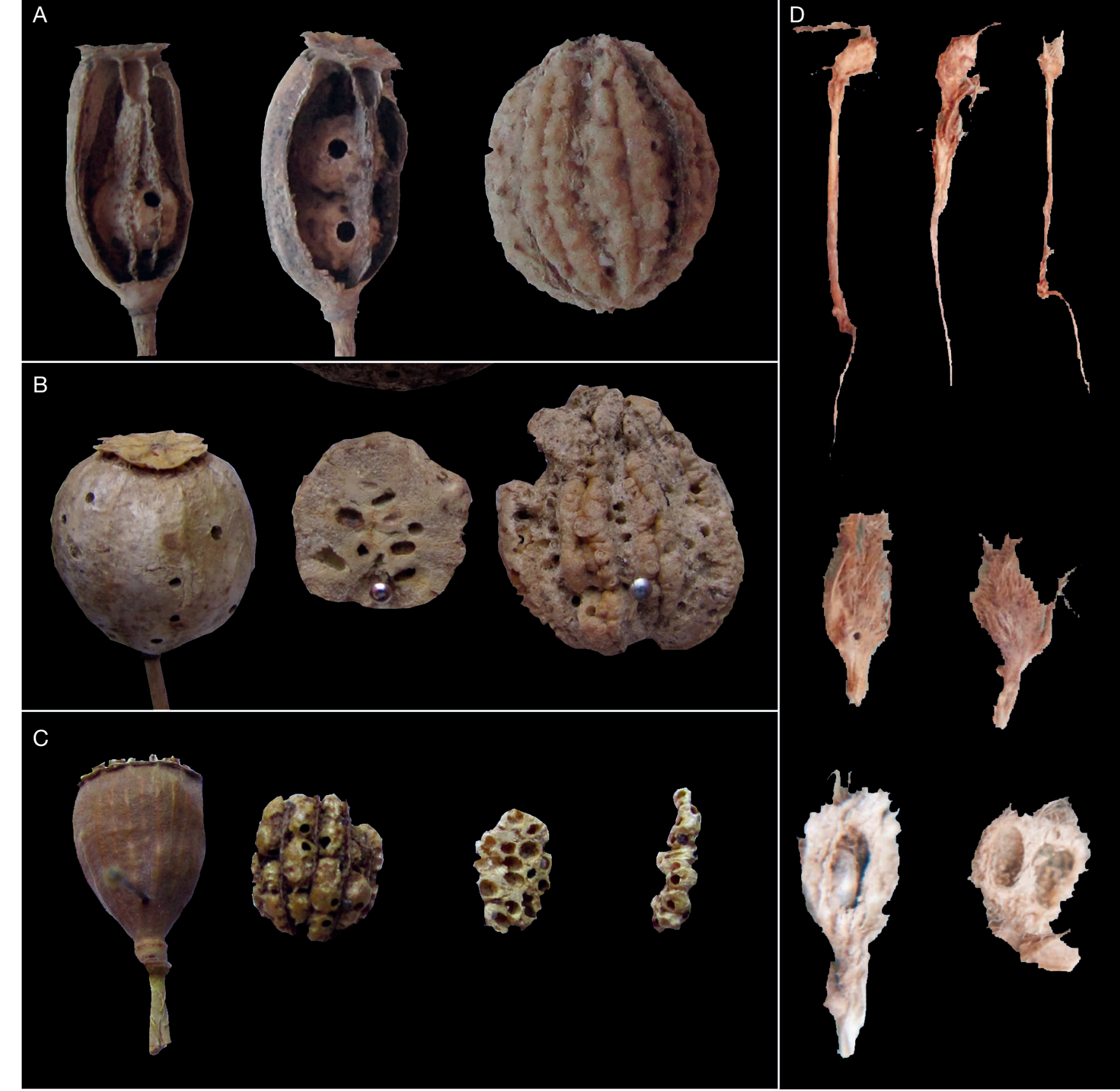

FIG. 4. - Galls of: A, Barbotinia oraniensis (Barbotin, 1964); B, Aylax papaveris (Perris, 1840); C, A. minor Hartig, 1840; D, Iraella ionescui n. sp.

in two different organs of host plant (leaves and midrib or flower head and stem). In all these cases the galls are similar and the adults identical. The species morphologically similar to I. ionescui $\mathrm{n}$. sp. is I. hispanica, nevertheless, the galls of this new species are invariably unilocular and always found at the stem base whereas galls made by I. hispanica are plurilocular in terminal flowers buds. So far, no galls made by Iraela species, nor galls collected in puppies, have different morphology although these species have been abundantly collected in all European and circum-Mediterranean regions. This further support $I$. ionescui n. sp. as a new species, rather than being conspecific with I. hispanica support.
Parasitoids inducing galls on PapaVer

According to Askew et al. (2006) a total of 20 species of parasitoids are associated with the cynipid galls on Papaver (Table 1), one species belongs to Figitidae (Parnips nigripes) while the rest are Chalcidoidea.

Parnips nigripes was originally described as a gall wasp in the Aulacidea genus (Barbotin 1964). Although Ronquist (1994) considered this species to be a figitoid inquiline, Ronquist $\&$ Nieves-Aldrey (2001) concluded that Aulacidea nigripes is neither a gall inducer nor a phytophagous inquiline; rather it is a koinobiont parasitoid of Barbotinia oraniensis. Based on its phylogenetic position, Ronquist \& Nieves-Aldrey 2001 
TABle 1. - Parasitoids associated to Aylacini Ashmead, 1903 species in Papaver galls according to Askew et al. (2006): AD, Andorra; AL, Algeria; AT, Austria; BG, Bulgaria; DE, Germany; ES, Spain; FR, France; GB, Great Britain; GR, Greece; HR, Croatia; HU, Hungary; PT, Portugal; RO, Romania (bold). Symnew record from Romanian fauna or from these galls in Romania. (1) corresponds to Eupelmus vesicularis (Retzius, 1783) species "complex A" sensu Fusu (2010) and (2) Eupelmus vesicularis species "complex B" sensu Fusu (2010).

\begin{tabular}{|c|c|c|c|c|c|c|}
\hline PARASITOIDS & $\begin{array}{l}\text { Aylax minor } \\
\text { Hartig, } 1840\end{array}$ & $\begin{array}{c}\text { Aylax } \\
\text { papaveris } \\
(\text { Perris, 1840) }\end{array}$ & $\begin{array}{c}\text { Barbotinia } \\
\text { oraniensis } \\
\text { (Barbotin, 1964) }\end{array}$ & $\begin{array}{l}\text { Iraella luteipes } \\
\text { (Thomson, } \\
\text { 1877) }\end{array}$ & $\begin{array}{l}\text { Iraella hispanica } \\
\text { Nieves-Aldrey, } \\
2005\end{array}$ & $\begin{array}{l}\text { Iraella } \\
\text { ionescui } \\
\text { n. sp. }\end{array}$ \\
\hline \multicolumn{7}{|l|}{ Figitidae Thomson, 1862} \\
\hline Parnips nigripes (Barbotin, 1963) & & & AL, ES, RO & & ES & RO* \\
\hline \multicolumn{7}{|l|}{ Chalcidoidea Latreille, 1817} \\
\hline $\begin{array}{l}\text { Eulophidae Westwood, } 1829 \\
\text { Aprostocetus forsteri^ (Walker, 1847) } \\
\text { Aprostocetus sp. } \\
\text { Baryscapus papaveris Graham, } 1991\end{array}$ & $\begin{array}{l}\text { RO* } \\
\text { RO* } \\
\text { FR }\end{array}$ & $\begin{array}{c}\mathrm{RO}^{*} \\
\mathrm{ES}, \mathrm{FR}\end{array}$ & $\begin{array}{l}\text { ES } \\
\text { ES }\end{array}$ & & & \\
\hline $\begin{array}{l}\text { Eupelmidae Walker, } 1833 \\
\text { Eupelmus aseculatus }{ }^{\star} \text { (Kañlina, 1981) } \\
\text { Eupelmus atropurpureus }{ }^{\star} \text { Dalman, 1820 } \\
\text { Eupelmus microzonus Förster, 1860 } \\
\text { Eupelmus vesicularis (Retzius, 1783) } \\
\text { Eupelmus sp. }\end{array}$ & $\begin{array}{l}\text { FR, RO* } \\
\text { ES, PT } \\
\text { FR, RO* }\end{array}$ & $\begin{array}{l}\mathrm{ES} \\
\mathrm{FR} \\
\mathrm{GB} \\
\mathrm{RO}^{*}\end{array}$ & $\begin{array}{c}\mathbf{R O}^{*} \\
\mathrm{ES}, \mathbf{R O}^{*} \\
\mathbf{R O}^{*}, 1,2\end{array}$ & ES & & $\begin{array}{c}\mathbf{R O}^{\star} \\
\mathbf{R O}^{\star}, 1,2\end{array}$ \\
\hline $\begin{array}{l}\text { Eurytomidae Walker, } 1832 \\
\quad \text { Eurytoma ?jaceae Mayr, } 1878 \\
\text { Eurytoma cynipsea Boheman, } 1836 \\
\text { Eurytoma infracta Mayr, } 1904 \\
\text { Eurytoma robusta Mayr, } 1878 \\
\text { Eurytoma sp. } \\
\text { Sycophila mellea Curtis, } 1831 \\
\end{array}$ & $\begin{array}{l}\text { ES } \\
\text { RO* }\end{array}$ & $\mathrm{FR}$ & $\begin{array}{c}\mathrm{ES}, \mathbf{R O} \\
\mathbf{R O}^{*}\end{array}$ & $\begin{array}{l}\text { ES } \\
\text { ES }\end{array}$ & & $\mathbf{R O}^{*}$ \\
\hline $\begin{array}{l}\text { Ormyridae Förster, } 1856 \\
\text { Ormyrus capsalis Askew, 1994 } \\
\text { Ormyrus papaveris (Perris, 1840) } \\
\text { Ormyrus sp. }\end{array}$ & $\begin{array}{c}E S, F R \\
A D, E S, F R, R O^{*}\end{array}$ & $\begin{array}{l}\text { ES, FR } \\
\text { AT, DE, ES, FR, } \\
\text { GB, HU, }\end{array}$ & $\begin{array}{l}\text { ES } \\
\text { ES } \\
\mathbf{R O}^{*}\end{array}$ & & & \\
\hline $\begin{array}{l}\text { Pteromalidae Dalman, } 1820 \\
\text { Homoporus subniger (Walker, 1835) } \\
\text { Mesopolobus sp. } \\
\text { Pteromalus hieracii (Thomson, 1878) } \\
\text { Pteromalus papaveris Förster, 1841 } \\
\text { Pteromalus sp. } \\
\text { Trichomalus sp. nr tenellus (Walker, 1834) } \\
\text { Trichomalus tenellus (Walker, 1834) }\end{array}$ & $\begin{array}{c}\text { RO* }^{*} \\
\text { FR, GB }\end{array}$ & $\begin{array}{c}\mathrm{GB} \\
\mathrm{DE}, \mathrm{GB}\end{array}$ & $\begin{array}{l}\text { RO* }^{*} \\
\text { RO* }^{*}\end{array}$ & $\begin{array}{l}\text { ES } \\
\text { ES }\end{array}$ & & RO* \\
\hline $\begin{array}{l}\text { Torymidae Walker, } 1833 \\
\text { Chalcimerus borceai Steffan \& } \\
\text { Andriescu, } 1962 \\
\text { Glyphomerus tibialis Förster, } 1856 \\
\text { Idiomacromerus mayri (Wachtl, 1883) } \\
\text { Idiomacromerus papaveris Förster, } \\
1856 \\
\text { Torymus sp. }\end{array}$ & $A D, E S, F R, R O^{*}$ & $\begin{array}{c}\text { ES, FR, HR, } \\
\text { HU, RO** }\end{array}$ & $\begin{array}{l}\text { AL, BG, ES, GR, } \\
\text { RO } \\
\text { ES } \\
\text { RO* } \\
\text { ES } \\
\text { RO* }\end{array}$ & & & $\mathbf{R O}^{*}$ \\
\hline
\end{tabular}

established a new genus and subfamily (Parnipinae: Parnips) for the species. Nonetheless, these authors did not designate the lectotype in spite of having examined the syntypes in the Barbotin collection. Therefore, we herein designate the lectotype (P), which is deposited in coll. JP-V and bears the following labels: "Oran Pap. rhoeas, iii-60" (white label), "Lectotype of Aulacidea nigripes Barbotin, 1964, design. JP-V 2013” (red label), "Parnips nigripes (Barbotin) JP-V det." (white label). The paralectotypes are also deposited in JP-V collection $\left(240^{7}, 40 \%\right)$ and bear similar labels as the Lectotype (Assi Bou Nif, III.62: $10^{7}, 1$ \% ; Murdjadjo, III.61 \& III.62: $140^{7}$, 20 \%; Manguin, III.62: 1 ơ, 2 \%; Moulay Ismael, III.62: $10^{\prime \prime}$, 1 \% : Misserghin, III-IV.62: 1 ơ 10 \%; Oran, III-60 \& II-61: III.62: $10^{7}, 6$ ㅇ.
Nieves-Aldrey (2005) also obtained material of Parnips from Iraella hispanica and suggested that those specimens belong to a new species of Parnips based on a molecular analysis. Since no morphological difference was observed in comparison to P. nigripes (Nieves-Aldrey 2005) and he proposed that the specimens obtained from I. hispanica could be a sibling species of $P$. nigripes. We have some specimens of Parnips from Iraella ionescui n. sp. galls, and after examining tens of specimens, also did not found any morphological difference between these specimens and P. nigripes.

On Papaver galls, the most species of Chalcidoidea obtained are new for the Romanian fauna (Table 1); only two species were known previously (Andriescu 1971): Eurytoma infracta Mayr, 1904 and Chalcimerus borceai Stefan \& Andriescu, 1962, both 
on Barbotinia oraniensis. Four species are new for the Romanian fauna: Aprostocetus forsteri (Walker, 1847) and Baryscapus papaveris Graham, 1991 (Eulophidae), Eupelmus aseculatus Kañlina, 1981 and E. atropurpureus Dalman, 1820 (Eupelmidae), according to Noyes (2012). The material was determined by Andriescu during 1994-2000; unfortunately some species were only determined to genus level: Aprostocetus sp. not belonging to A. forsteri, Eurytoma sp. not belonging to Eurytoma infracta and similar to Eurytoma robusta Mayr, 1878, Mesopolobus sp. and Torymus sp., which have never been cited in these galls, Ormyrus sp. not belonging to O. papaveris (probably belonging to O. capsalis Askew, 1994), Pteromalus sp. (probably belonging to $P$. hieracii (Thomson, 1878) or $P$. papaveris Förster, 1841). The other twelve species are determined to species (Table 1).

In the new species, Iraella ionescui n. sp., the parasitoids obtained are: Parnips nigripes, Eupelmus atropurpureus, E. vesicularis (Retzius, 1783) (sensu Fusu 2010), Eurytoma robusta, Idiomacromerus mayri (Wachtl, 1883), Mesopolobus sp. and Trichomalus tenellus (Walker, 1834). These results contrast with $I$. hispanica where chacidoids have never been obtained.

\section{Acknowledgements}

We are grateful to Ionel Andriescu (University Iaşi, Romania) for determining the chalcidoid fauna obtained from Papaver galls, to Lucian Fusu and Mircea Mitroiu (University Iaşi, Romania) for determining first Eupelmidae and second Pteromalidae. We also thank the two referees Zhiwei Liu and György Csóka whose comments improved our works.

\section{BIBLIOGRAPHY}

ANDRIESCU I. 1971. — Calcidoide (Chalcidoidea Hym. Insecta) din colectia muzeului de istorie naturala "Gr. Antipa" din Bucuresti. Lucrärile Statiunii de Cercetãri Biologice, Geologice si Geografice "Stejarul". Biologie 4: 425-444.

ANDRIESCU I. 1983. - On the role of climatic barrier in limiting the area of the phytophagous insects, the case of Cynipidae (Hymenoptera) which develop in the capsules of corn poppy (Papaver rhoeas L. and P. dubium L.), Verh. SIEEC X, Budapest: 155-157.

Askew R. R., Plantard O., Gómez J. F., Nieves M. H. \& NievesALDREY J. L. 2006. - Catalogue of parasitoids and inquilines in galls of Aylacini, Diplolepidini and Pediaspidini (Hym., Cynipidae) in the West Palaearctic. Zootaxa 1301: 1-60.

BARBOTIN F. 1964. - Sur une nouvelle galle et deux nouveaux cynipides en provenance d'Algérie. Marcellia 31: 151-157.

EADY R. D. \& QUINLAN J. 1963. - Hymenoptera Cynipoidea Key to families and subfamilies and Cynipinae (including galls). Handbooks for the identification of British Insects 8 (1a): 1-81.

Folliot R. 1964. - Contribution à l'étude de la biologie des Cynipides gallicoles (Hyménoptères, Cynipoidea). Annales des Sciences naturelles, Zoology 12, Ser. 6: 407-564.

FUSU L. 2010. - Species status of two color morphs of Eupelmus vesicularis (Hymenoptera: Eupelmidae) as revealed by allozyme electrophoresis, morphometric and host preference data. Journal of Natural History 44 (17-18): 1113-1129.
HARRIS R. 1979. - A glossary of surface sculpturing. State of California, Department of Food and Agriculture. Occasional Papers of Entomology 28: 1-31.

HARTIG T. 1840. — Ueber die Familie der Gallwespen. III. Zeitschrift für Entomologie (Germar) 2: 176-209

IONESCU M. A. 1957. - Cynipinae in: Fauna Republicii Populare Romina, Vol. IX-2. Academi Republicii Populare Romine. Bucaresti, 246 p. [in Romanian].

IONESCU M. A., 1973. — Biologia Galelor. Monografie Cecidologica [Biology of gall inducers. Monography on Cecidology.] Academia Republicii Populare România Press, Bucuresti 178 p. [in Romanian]

Karimpour Y., TAVAKoli M. \& Melika G. 2008. — New species of herb gallwasps from the Middle East (Hymenoptera, Cynipidae, Aylacini). Zootaxa 1854: 16-32.

KWAST E. 2012. - A contribution to the fauna of Cynipidae (Insecta, Hymenoptera, Synipidae) of Croatia with a description of an asexual female of Andricus korlevici (Kieffer, 1902) nov. comb. Natura Croatica, 21 (1): 223-245.

LILJEBLAD J. \& RONQUIST F. 1998. - A phylogenetic analysis of higher-level gall wasp relationships (Hymenoptera: Cynipidae). Systematic Entomology 23: 29-252.

MeLIKA G. 2006. - Gall Wasps of Ukraine. Cynipidae. Vestnik zoologii, supplement 21 (1): 1-300.

MelikA G. \& GHaraei B. 2006. - New species of aylacine gall wasps from Iran (Hymenoptera: Cynipidae: Aylacini). Acta Zoologica Academiae Scientiarum Hungaricae 52 (4): 385-399.

MeliKa G. \& Karimpour Y. 2012. - Herb gallwasp fauna of Iran (Hymenoptera: Cynipidae, Aylacini). North-Western Journal of Zoology 8 (2): 268-277.

NiEVES-ALDREY J. L. 1994. — Revision of West-European Genera of the Tribe Aylacini Ashmead (Hymenoptera, Cynipidae). Journal of Hymenoptera Research 3: 175-206.

Nieves-AldRey J. L. 2001. - Hymenoptera, Cynipidae, in Ramos M. A., Alba Tercedor J., Bellés I Ros X., Gosálbez I Noguera J., Guerra Sierra A., Macpherson Mayol E., Martín Piera F., Serrano Marino, J. \& J. Templado González (eds) Fauna Ibérica, vol. XVI, Museo Nacional de Ciencias Naturales (CSIC), Madrid, $636 \mathrm{p}$.

NiEVES-AlDREY J. L. 2005. - A new species of Iraella Nieves-Aldrey (Hymenoptera: Cynipidae), from Northeastern Spain, inducing galls on Papaver (Papaveraceae). Annals of the Entomological Society of America 98 (6): 853-860.

NOYES J. S. 2012. - Universal Chalcidoidea Database. World Wide Web electronic publication. http://www.nhm.ac.uk/chalcidoids [consulted May-2013].

Nylander J. A., Ronquist F., Huelsenbeck J. P. \& NieVes-Aldrey J. L. 2004. - Bayesian phylogenetic analysis of combined data. Systematic Biology 53 (1): 47-67.

PERRIS M. E. 1840. - Observations sur les insectes que habitent les galles de l'Ulex nanus et du Papaver dubium. Annales de la Société entomologique de France 9 (1839): 89-99.

RONQUIST F. 1994. - Evolution of parasitism among closely related species: phylogenetic relationships and the origin of inquilinism in gall wasps (Hymenoptera, Cynipidae). Evolution 48: 241-266.

RONQUiST F. \& Nieves-AldRey J. L. 2001. — A new subfamily of Figitidae (Hymenoptera, Cynipidae). Zoological Journal of the Linnean Society of London, 133: 483-493.

RONQUisT F. \& NORDLANDER G. 1989. — Skeletal morphology of an archaic cynipoid, Ibalia rufipes (Hymenoptera: Ibaliidae). Entomologica scandinavica Supplement 33: 1-60. 
